\title{
A Review of Outstanding Retinoblastoma Researches on RB1 Genes: Focus on Treatment by Non-ionizing and Ionizing Radiation
}

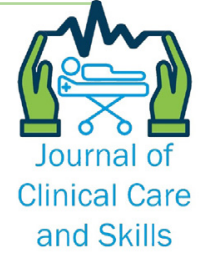

and Skills

\section{ARTICLE INFO}

\section{Article Type}

Analytical Review

\section{Authors}

Nedaei K. ${ }^{1} B S c$,

Salehi Z. ${ }^{1} P h D$,

Alipoor B. ${ }^{2} P h D$,

Jafarzadeh M. ${ }^{1} B S C$

Aljamal M.*3 $P h D$,

Zoladl M. ${ }^{4} \mathrm{PhD}$

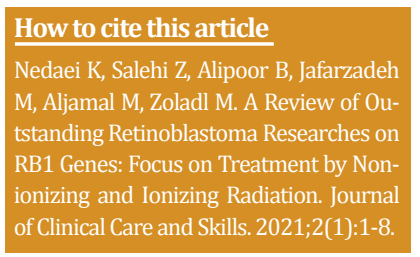

${ }^{1}$ Department of Radiation Sciences, School of Paramedical Sciences, Yasuj University of Medical Sciences, Yasuj, Iran

${ }^{2}$ Department of Laboratory Sciences, School of Paramedical Sciences, Yasuj University of Medical Sciences, Yasuj, Iran

${ }^{3}$ Department of Medical Radiation, Faculty of Allied Medical Sciences, Arab American University, Jenin, Palestine

${ }^{4}$ Social Determinants of Health Research Center, Yasuj University of Medical Sciences, Yasuj, Iran

\section{*Correspondence}

Address: Department of Medical Radiation, Faculty of Allied Medical Sciences, Arab American University, Jenin, Palestine.

Phone: -

Fax: -

mohammad.aljamal@aaup.edu

\section{Article History}

Received: November 16, 2019

Accepted: August 09, 2020

ePublished: February 01, 2021

\section{A B S T R A C T}

Introduction Retinoblastoma (RB) is a malignant retinal tumor, which affects infants and children. This cancer happens through a mutation in the retinoblastoma tumor suppressor genes (RB1). Inactivation of RB1 has been observed in more than $97 \%$ of all retinoblastoma patients with mutations. In recent years, RB treatment has developed significantly. RB's treatment methods can be one or a combination of the following treatments, including chemotherapy, non-ionizing, or ionizing radiation. This article aimed to review each treatment method's role and its effectiveness in the treatment of RB. Several articles from 2004 to 2020 were reviewed in PubMed, Web of Science, Google Scholar, and Scopus, based on the RB treatments, of which 73 were selected for this study.

Conclusion It can be concluded that ionizing and non-ionizing radiation play an important role in treating retinoblastoma. It was also shown that a combination of radiation treatments is more effective than traditional therapeutic methods.

Ionized and non-Ionized radiations can be used as an effective treatment to cure retinoblastoma.

Keywords Retinoblastoma; Treatment; RB1 Gene; Ionizing Radiation; Non-Ionizing Radiation

\section{I T A T I O N L I N K S}

[1] A polymorphism in mir-34b ... [2] Association between MDM2 ... [3] Retinoblastoma for pediatric ... [4] Retinoblastoma update ... [5] Translating microRNAs into ... [6] 2014 recommendations for ... [7] Comprehensive screening for ... [8] A rapid and sensitive next-... [9] Developmental stage-specific ... [10] Retinoblastoma incidence patterns ... [11] Ethnic, racial, ... [12] Epidemiological trends in 1452 ... [13] Racial and ethnic disparities ... [14] Epidemiology of childhood ... [15] Malignant tumours of the ... [16] The Children's Oncology ... [17] Sporadic unilateral ... [18] Maternal and birth characteristics ... [19] Smoking in pregnancy and ... [20] Clinical presentation and ... [21] Sporadic retinoblastoma ... [22] Retrospective investigation ... [23] Intersection of retinoblastoma ... [24] Diseases of DNA repair ... [25] Treatment of retinoblastoma ... [26] Systemic chemotherapy as ... [27] Incidence of new tumor ... [28] Impact of systemic chemotherapy ... [29] New therapeutic strategies ... [30] Incidence of second cancers ... [31] The international classification ... [32] Chemoreduction for group ... [33] Outcomes of a two-drug ... [34] Secondary acute myelogenous ... [35] Superselective intra-arterial ... [36] Intraarterial chemotherapy ... [37] Intra-arterial chemotherapy ... [38] Ophthalmic artery chemosurgery ... [39] First-line intra-arterial ... [40] Alternated intra-arterial and ... [41] Intravitreal melphalan for ... [42] Intravitreal chemotherapy ... [43] Intravitreal melphalan for ... [44] Intravitreal lower-Dose (20 $\mu \mathrm{g})$... [45] Intravitreal melphalan for vitreous ... [46] Efficacy and toxicity of ... [47] Use of non-ionizing ... [48] Phase I trial of interleukin ... [49] Non-ionizing radiation with ... [50] Tissue ablation with irreversible ... [51] Tumor-targeted photodynamic ... [52] DNA duplex-based photodynamic ... [53] In vivo efficacy of photodynamic ... [54] Efficient photodynamic ... [55] Biological effects and medical ... [56] Low-level light/laser ... [57] Absorption of monochromatic ... [58] Mitochondrial signaling in ... [59] Proposed Mechanisms of Photobiomodulation ... [60] Photo-infrared pulsed ... [61] Non-thermal near-infrared ... [62] Impact of preoperative local ... [63] Ionizing radiation ... [64] The minimal set of genetic ... [65] Telomerase activation ... [66] Unilateral retinoblastoma in ... [67] The human retinoblastoma ... [68] G2-phase chromosomal ... [69] The Rb1 gene inhibits the ... [70] Role of the retinoblastoma ... [71] The E2F family: Specific ... [72] E2F1 promotes the ... [73] E2F1 localizes to sites ... 


\section{Introduction}

Retinoblastoma (RB) is a malignant retinal tumor that affects newborns and children [1-4]. The most common sign of this cancer is a white pupil reflex called leukocoria [3,5,6]. Most of the patients are at risk due to long-standing diagnosis [5]. Diagnosis of pediatric cancer is still dependent on clinical symptoms, which may be non-specific or sometimes appear in later stages. Therefore, there is a need to understand better molecules that provide less invasive, early, and effective detection of cancer [7]. Retinoblastoma happens by a mutation in the $R B 1$ gene. Mutations in both $R B 1$ alleles are essential in precursor retinal cells, with the first mutation may be germline or somatic, and the second, which is always somatic [1, 8, 9]. Early identification of $R B 1$ gene mutations in blood samples or somatic $R B 1$ mutations in tumors is important for the care and management of patients with retinoblastoma and their families [10]. Retinoblastoma accounts for approximately $11 \%$ of cancers occurring in the first year of life, with $95 \%$ diagnosed before 5 years of age [11]. Multiple studies indicated that age is an important risk factor of RB, while other investigations showed various factors could affect early detection of such disease, including racial, ethnic, and socioeconomic factors [11-16]. The low socioeconomic status will remarkably affect the degree of illness and outcomes of the eye due to the possibility of treatment limited by the access to primary and direct cancer care [17]. Some research showed that when the birth order increased, a decreasing risk was observed for other tumor types in the research except for retinoblastoma [18-21]. Some studies have been carried out to check clinical outcomes and treatment in children in southwestern China with retinoblastoma and distinguish the predictive factors for bad outcomes. The study showed that parents' and physicians' education for early retinoblastoma symptoms such as leukocoria, therapeutic strategy, and retinoblastoma treatment outcomes might improve early detection, improvement of compliance, and disease outcome [22, 23].

This study aims to investigate the effects of all types of radiation, both ionizing and non-ionizing, on $\mathrm{RB}$ treatment. In this research, the following question has been answered: How can ionizing and nonionizing radiation be used as an effective method to cure RB cancer?

In this review, the original scientific articles published after 2000 on the effects of ionized and non-ionized radiation on retinoblastoma were reviewed through MEDLINE, PubMed, Web of Science, Google Scholar, and Scopus databases. Keywords "Radiation therapy" or Radiotherapy" or "Radiation" or "X-ray" or "Gamma-ray", AND "Retinoblastoma" AND, "Ionized" or "Non-ionized" or "Ionizing' or "Non-ionizing" were applied.
Original scientific articles published in English, as well as studies reporting the source of the radiation, dose, and sample size, were only selected (research criteria).

Eligible articles were comprehensively reviewed by one of the authors (Dr. M. Aljamal) based on the research criteria. The article's selection started with screening the title, abstract, and conclusion of the article; the next step, the articles that met the criteria were selected. Finally, 73 articles were selected for this study.

\section{Treatments for retinoblastoma}

Due to a mutation of 1 of 2 RB1 genes in all somatic cells, the patients with hereditary retinoblastoma are in danger of inducing secondary cancer ${ }^{[24]}$. The various aspects must be considered in choosing the suitable treatment options for retinoblastoma, which can be included: unilateral/bilateral case, size and location of the lesion, the possibility of losing the vision, and hereditary nature of this disease [4]. The most common treatment methods for retinoblastoma are chemotherapy, ionizing radiation (external radiation therapy and brachytherapy), and nonionizing radiation (laser photocoagulation). Some treatment methods of most unilateral cases and some bilateral cases have reduced the use of external beam radiotherapy and systemic chemotherapy such as ophthalmic artery chemosurgery and intravitreous chemotherapy; therefore, the most metastatic disease can be curable now [25]. In this paper, the treatment option for retinoblastoma is reviewed to study each treatment method's efficiency on RB treatment.

\section{Chemotherapy treatment}

Chemo-reduction treatment played an important role as a conservative option in children with intraocular retinoblastoma and even in children with advanced cases of this disease [26]. The charts of 58 consecutive patients with hereditary retinoblastoma treated between January 1996 and August 2005 were reviewed. Wilson et al. found that young patients treated using systemic chemotherapy for RB may effectuate small previously undetected lesions by slowing their growth [27]. Zhao et al. divided children with retinoblastoma into groups D and E in 29 treatment centers and found that using chemotherapy before enucleation may not has the impact or the benefit for the patient. On the contrary, the enucleation could minimize the risk of the spread of cancer to other organs. While Post-enucleation chemotherapy showed an effective method to improve children's survival rate with high-risk histopathology [28]. Systemic chemotherapy may increase morbidity and the risk of inducing a secondary malignancy [29]. Besides, it is the strongest risk factor for second malignancies outside the periorbital region. Therefore, instead of systemic chemotherapy, another treatment option was 
recommended to reduce the risk effect after this treatment method [30]. Intravenous chemotherapy (IVC) is an effective way to treat early-stage retinoblastoma, especially classified under groups A, $B$, and $C$, where the studies showed that the survival rate could reach $100 \%$ but still for RB groups D and E requires enucleation with IVC. In this study, 249 cases were examined [31, 32]. IVC is related to some systemic side effects that cannot be avoided, such as hearing loss, which might induce myelogenous leukemia [33, 34]. Another method was Intra-arterial chemotherapy (IAC), where this method was introduced basically for advanced cases of retinoblastoma after the intravenous chemotherapy has failed in the treatment process. Therefore, some centers tried to use the IAC method as a primary treatment for advanced cases of RB and showed significant improvement to prevent the enucleation option [35-40]. Recently, intravitreal chemotherapy has shown an effective way to control vitreous seeds. Several studies have been conducted to check the effectiveness of this treatment, and they found that intravitreal chemotherapy is a reliable and efficient method for the treatment of vitreous cases [41-46].

\section{Non-ionizing radiation treatment}

The treatment of cancer and cure options are limited in some cases. For example, when the tumor is inoperable [47]. New Findings show that targeting and treating cancer by non-ionizing radiation is a new important goal in cancer treatment. Although electromagnetic fields (EMFs) have been used in medical applications for diagnostic or therapeutic purposes, non-ionizing EMF's can be considered as a novel method in treating cancer cells [47]. There are varieties of new treatment strategies, which use electroporation for the treatment of cancer. The electro-gene transfer method was used to benefit from delivering genes, guiding the immune system against the tumors [47]. Electrochemotherapy is another strategy that uses electroporation to deliver a chemotherapeutic agent, and irreversible electroporation uses the electroporation to induce necrosis $[27,28]$. Other methods were suggested using temperature to treat cancer, such as cryotherapy, which induces thermal necrosis by freezing and radiofrequency ablation [48].

The ion-ionizing radiation with nanosecond pulsed electric fields (nsPEFs) has shown a brilliant treatment method at local sites [41]. In this study, results were obtained among 12 treated cases, in which 10 out of 12 cases were performed at immediate follow-up, 8 out of 10 cases at short-term follow-up, and 6 out of 10 cases at long-term followup, the presence of the active caspase (one of the apoptosis hallmarks), Yo-PRO-1 uptake (which probably identifies apoptotic cells), and propidium iodide (PI) uptake (which act as the measure of membrane integrity) were investigated in B16f10 cells. Their findings showed that nsPEFs induced cell death in $90-95 \%$ of cells in murine B16f10 melanoma, murine E4 squamous carcinoma, murine Hep16, and human HepG2 hepatocellular carcinoma [41]. In other researches, it has been shown that photodynamic therapy (PDT) could also act as a suitable clinical method for cancer treatment. It contains a local or systemic administration of a photosensitizer, followed by irradiating a target lesion with a certain wavelength of non-ionizing light, which results in oxidative photo-damage and finally the targeted death cells [49, 50]. The importance of infrared (IR) therapy has also grown rapidly in recent years ${ }^{[51-54]}$. Two kinds of therapies are usually employing the lights at red and near-infrared wavelengths (600$100 \mathrm{~nm}$ ) to modulate biological activity, which can be classified as Low-level light therapy and Photobiomodulation (PBM) therapy. The Low-level light therapy (LLLT) acts as a treatment method using a low intensity of light, so the effect is based on response to the light and not due to heat or thermal effect, and it uses a variety of light sources, especially low-power lasers to kill cancer cells [55, 56]. While Photobiomodulation (PBM) therapy technique uses a form of light therapy that utilizes non-ionizing forms of light sources, like light-emitting diodes (LEDs) and lasers in the visible and infrared spectrum. This nonthermal process has suitable therapeutic outcomes, including alleviating pain or inflammation, immunomodulation, and promotion of wound healing and tissue regeneration [55, 56]. IR-induced physiological effects are claimed to be due to two basic kinds of photo acceptor: cytochrome c oxidase (CCOX) and intracellular water $[55,56]$. The water dynamics in membranes, mitochondria, and/or cells absorb the IR photons, which converts light into signals that can stimulate biological processes [57]. During cancer, patients can be exposed to a variety of radiation types. Low doses of ionizing radiation are used for medical imaging applications (1-10 mGy). On the other hand, high doses of radiation play an important role in cancer radiotherapy to destroy malignant tissue (fractionated up to a local dose of 80 Gy) [55, 58-60]. In new research in 2018, it is pointed that ionizing and near-infrared radiation can both play a well therapeutic role in cancer treatment [61, 62]. Ionizing radiation is typically used for non-invasive malignant tissue reduction, but near-infrared photobiomodulation is applied for narcotic approaches, such as pain reduction or impairment of wound healing [61, 62]. Combined exposure of these two irradiation types is finally suitable for cancer patients. The research suggested that the cancer patients treated with X-rays should be prevented from uncontrolled near-infrared (NIR) irradiation, while controlled double-treatment could provide an alternative therapy approach, exposing the patient to less radiation [61, 62]. A brief table summarizes some previous studies on the response of retinoblastoma 
disease to non-ionizing radiation (Table 1 ).

\section{Ionizing radiation treatment}

Telomeres are nucleoprotein sets that protect the linear chromosomes from fusion and decomposition and play an important role in maintaining DNA integrity [61, 62]. The shortening of telomeres due to DNA replication leads to aging of the cell in most somatic cells [63, 64]. Telomerase is a unique ribonucleoprotein reverse transcriptase that synthesizes telomeric repeats [63,64]. Normal somatic cells contain low telomerase activity (TA). On the other hand, $90 \%$ of all malignant cells express TA; thus, telomerase is one of the malignancy hallmarks [63, 64]. Activation of telomerase is considered important for malignant transformation and is essential for protecting the malignant clone [63, 64]. Obtaining a better understanding of the molecular mechanism of telomerase activation by ionizing radiation in retinoblastoma cells is important because patients suffered from retinoblastoma and treated with ionizing radiation are at risk for secondary cancers $[63,64]$. DNA damage induced by ionizing radiation at doses of 2-5 Gy could increase telomerase activity while using doses greater than 10 Gy might decrease telomerase activity in Y79 cell lines [65].

Furthermore, it has been shown that telomerase activity is increased 12-24 hours after the radiation dose of less than $10 \mathrm{~Gy}{ }^{[65]}$. Although the extent of activation or inhibition of telomerase with ionizing radiation depends on the cell type and the experimental setting, the mechanism of regulating telomerase in a radiation-dose dependent manner is still poorly understood [65]. The latest researches on $R B 1$ have shown that the mutation on chromosome $13 q$ is often present in retinoblastoma tumors [65]. The $R B 1$ gene has an important role in regulating the cell cycle, cell differentiation, cell aging, apoptosis, and growth suppression [66-68]. Yang et al. reported that $R B 1$ could be functionally inactivated through many kinds of mechanisms, such as deregulated phosphorylation and direct sequestration by oncoproteins and the loss of $R B 1$ function leads to a breakdown in genome integrity [66-68]. The E2F group of transcription factors also has an important role in DNA repair. E2F1, known as the most important founding member of the E2F transcription factor family, promotes the recruitment and/or retention of repair factors, such as XPA and XPC, at the sites of DNA breaks and can repair DNA double-strand breaks (DSBs) [69-73]. The RB1-E2F1 complex is formed as a response to DNA damage and is recruited to the sites of DNA DSBs [69-73]. To analyze the DNA repair efficiency of exogenous RB1, SO-Rb50 cells transfected with the pcDNA3.1-Rb1 or pcDNA3.1vector were exposed to ionizing radiation [137Cs (dose rate, $0.67 \mathrm{~Gy} / \mathrm{min}$ )] [69-73]. The viability of RB1 of 50 cells was measured. It has been found that DNA repair efficiency was significantly increased following radiation-induced damage [69-73]. External beam radiotherapy has been a standard treatment option for large-sized lesions and intraocular retinoblastoma, but it markedly increases secondary cancer risk. A summary of some studies that have been conducted to study the efficiency of ionizing radiation on Retinoblastoma treatment (Table 2).

Table 1) Researches conducted to study the efficiency of non-ionizing radiation in the treatment of retinoblastoma disease

\begin{tabular}{|c|c|}
\hline Research & Specifications \\
\hline \multicolumn{2}{|l|}{ Beebe et al. 2009 [49] } \\
\hline Irradiated samples: & Tumor cells \\
\hline Radiation source: & nsPEFs \\
\hline Dose: & $\begin{array}{l}\text { one or ten } 60 \mathrm{~ns} \text { or } 300 \mathrm{~ns} \text { pulses at } \\
\text { various electric fields }\end{array}$ \\
\hline $\begin{array}{l}\text { Analysis time after } \\
\text { radiation: }\end{array}$ & Decreased \\
\hline Sample count: & Decreased \\
\hline Results: & $\begin{array}{l}\text { Results show four coincident } \\
\text { apoptosis markers in the major } \\
\text { population }(85-95 \%) \text { of cells }\end{array}$ \\
\hline Conclusion: & $\begin{array}{l}\text { nsPEFs can induce cell responses that } \\
\text { indicate apoptosis induction }\end{array}$ \\
\hline \multicolumn{2}{|l|}{ Wei et al. 2016 [52] } \\
\hline Irradiated samples: & Y79 and WERI-Rb1 \\
\hline Radiation source: & Laser \\
\hline Dose: & 10,30 , and $50 \mathrm{~J} / \mathrm{cm} 2$ \\
\hline $\begin{array}{l}\text { Analysis time after } \\
\text { radiation: }\end{array}$ & $48 \mathrm{hrs}$ \\
\hline Sample count: & Decreased \\
\hline Results: & The viability of Y79 cells decreased \\
\hline Conclusion: & $\begin{array}{l}\text { The beacon showed an efficient } \\
\text { imaging capability on retinoblastoma } \\
\text { cells and increased cell apoptosis } \\
\text { after PDT in vitro. }\end{array}$ \\
\hline \multicolumn{2}{|l|}{ Wei et al. 2016 [52] } \\
\hline Irradiated samples: & Tumor cells \\
\hline Radiation source: & Laser \\
\hline Dose: & $633-\mathrm{nm}(30 \mathrm{~J} / \mathrm{cm} 2)$ over $5 \mathrm{~min}$ \\
\hline $\begin{array}{l}\text { Analysis time after } \\
\text { radiation: }\end{array}$ & $72 \mathrm{hrs}$ \\
\hline Sample count: & Decreased \\
\hline Results: & $\begin{array}{l}\text { The apoptosis of tumor cells } \\
\text { increased }\end{array}$ \\
\hline Conclusion: & $\begin{array}{l}\text { The beacon showed an efficient } \\
\text { imaging capability on retinoblastoma } \\
\text { cells and increased cell apoptosis } \\
\text { after PDT in vitro. }\end{array}$ \\
\hline \multicolumn{2}{|l|}{ Aerts et al. 2010 [53] } \\
\hline Irradiated samples: & 3 RB1 models \\
\hline Radiation source: & Laser \\
\hline Dose: & 100 and $600 \mathrm{~mW}(75$ and $50 \mathrm{~J} / \mathrm{cm} 2)$ \\
\hline $\begin{array}{l}\text { Analysis time after } \\
\text { radiation: }\end{array}$ & $<70$ days \\
\hline Sample count: & No effect \\
\hline Results: & $\begin{array}{l}\text { Successful treatment of RB with PDT } \\
\text { is likely to depend on the tumor's } \\
\text { parameters like location and size. }\end{array}$ \\
\hline Conclusion: & $\begin{array}{l}\text { They still do not have a full } \\
\text { understanding of the mechanisms of } \\
\text { action of PDT in RB. }\end{array}$ \\
\hline
\end{tabular}


Continue of Table 1) Researches conducted to study the efficiency of non-ionizing radiation in the treatment of retinoblastoma disease

\begin{tabular}{|c|c|}
\hline Research & Specifications \\
\hline \multicolumn{2}{|c|}{ Walther et al. 2014 [54] } \\
\hline Irradiated samples: & Y79; WERI Rb1 cell lines and PRE cells \\
\hline Radiation source: & Laser \\
\hline Dose: & $60 \mathrm{~J} / \mathrm{cm} 2$ and $100 \mathrm{~mW} / \mathrm{cm} 2$ \\
\hline $\begin{array}{l}\text { Analysis time after } \\
\text { radiation: }\end{array}$ & 0 and 30 and $60 \mathrm{hrs}$ \\
\hline Sample count: & No effect \\
\hline Results: & $\begin{array}{l}\text { The immune system's activation, } \\
\text { combined with the low resistance } \\
\text { mechanism, makes PDT an ideal cancer } \\
\text { curative treatment. However, many } \\
\text { technical limitations are linked to the } \\
\text { dozen clinically approved } \\
\text { photosensitizers and limit their use too } \\
\text { few applications. }\end{array}$ \\
\hline Conclusion: & $\begin{array}{l}\text { PDT can be a therapeutic option for the } \\
\text { treatment of retinoblastoma and also a } \\
\text { promising therapeutic alternative. }\end{array}$ \\
\hline \multicolumn{2}{|l|}{ Konig et al. 2018 [61] } \\
\hline Irradiated samples: & Human fibroblasts \\
\hline Radiation source: & Near Infrared(NIR) \& X-Ray \\
\hline Dose: & $\begin{array}{l}600-1400 \mathrm{~nm} \text { for } 30 \mathrm{~min} \& 90 \mathrm{kV}, 33.7 \\
\mathrm{~mA}, 5.23 \mathrm{~Gy} / \mathrm{min}\end{array}$ \\
\hline $\begin{array}{l}\text { Analysis time after } \\
\text { radiation: }\end{array}$ & During $24 \mathrm{hrs}$ \\
\hline Sample count: & Decreased \\
\hline Results: & $\begin{array}{l}\text { NIR Pretreatment Delays Repair of X- } \\
\text { ray-induced DSBs }\end{array}$ \\
\hline Conclusion: & $\begin{array}{l}\text { Cancer patients treated with X-rays } \\
\text { should be prevented from uncontrolled } \\
\text { NIR irradiation. Nevertheless, controlled } \\
\text { double-treatment could be an } \\
\text { alternative therapeutic way. }\end{array}$ \\
\hline
\end{tabular}

Table 2) Researches conducted to study the efficiency of ionizing radiation in the treatment of retinoblastoma disease

\begin{tabular}{|c|c|}
\hline Research & Specifications \\
\hline \multicolumn{2}{|l|}{ Ram et al. 2009 [63] } \\
\hline Irradiated samples: & Tumor cells \\
\hline Radiation source: & X-Ray \\
\hline Dose: & 2 to $8 \mathrm{~Gy}$ \\
\hline $\begin{array}{l}\text { Analysis time after } \\
\text { radiation: }\end{array}$ & Up to $48 \mathrm{hrs}$ \\
\hline Sample count: & Not mentioned \\
\hline Results: & Telomerase was activated \\
\hline Conclusion: & $\begin{array}{l}\text { Radiation up-regulates telomerase } \\
\text { activity in cancer cells, and the } \\
\text { Telomerase activation due to radiation } \\
\text { may be a way of treating cancer }\end{array}$ \\
\hline \multicolumn{2}{|c|}{ Akiyama et al. 2013 [65] } \\
\hline Irradiated samples: & Y79 cells \\
\hline Radiation source: & X-Ray \\
\hline Dose: & 2 and 5 and $10 \mathrm{~Gy}$ \\
\hline $\begin{array}{l}\text { Analysis time after } \\
\text { radiation: }\end{array}$ & Up to $8 \mathrm{hrs}$ \\
\hline Sample count: & G2/M checkpoint increased \\
\hline Results: & $\begin{array}{l}\text { DNA damage induced by IR at doses of } \\
2-5 \text { Gy increased telomerase activity } \\
\text { in Y79 cells, but DNA damage induced } \\
\text { by IR at doses greater than } 10 \text { Gy } \\
\text { might decrease telomerase activity. }\end{array}$ \\
\hline Conclusion: & $\begin{array}{l}\text { Different activation ways may be } \\
\text { responsible for telomerase regulation. }\end{array}$ \\
\hline
\end{tabular}

Continue of Table 2) Researches conducted to study the efficiency of ionizing radiation in the treatment of retinoblastoma disease

\begin{tabular}{|c|c|}
\hline Research & Specifications \\
\hline \multicolumn{2}{|l|}{ Wilson et al. 2011 [68] } \\
\hline Irradiated samples: & RB fibroblast strains \\
\hline Radiation source: & у Ray (662 KeV) \\
\hline Dose: & 0 (sham) or 50 cGy or $1 \mathrm{~Gy}$ \\
\hline $\begin{array}{l}\text { Analysis time after } \\
\text { radiation: }\end{array}$ & $<26 \mathrm{hrs}$ \\
\hline Sample count: & Decreased \\
\hline Results: & $\begin{array}{l}\text { The cells' inability to proliferate during } \\
\text { continuous low-dose-rate irradiation } \\
\text { at higher dose rates correlated with } \\
\text { cell cycle redistribution and } \\
\text { checkpoint-induced arrest in the } \\
\text { radiosensitive G2 phase of the cell } \\
\text { cycle. }\end{array}$ \\
\hline Conclusion: & The RB1 Radio-sensitivity increased \\
\hline \multicolumn{2}{|l|}{ Yang et al. 2013 [69] } \\
\hline Irradiated samples: & SO-Rb50+pcDNA3.1-RB1 \\
\hline Radiation source: & X-Ray \\
\hline Dose: & 0 and 2.5 and 5 Gy \\
\hline $\begin{array}{l}\text { Analysis time after } \\
\text { radiation: }\end{array}$ & $0,2.5,8,24 \mathrm{hrs}$ \\
\hline Sample count: & Decreased \\
\hline Results: & $\begin{array}{l}\text { Rb1 did not affect non-homologous } \\
\text { end joining (NHEJ) activity, although it } \\
\text { significantly promoted the } \\
\text { homologous recombination (HR) } \\
\text { pathway }\end{array}$ \\
\hline Conclusion: & $\begin{array}{l}\text { The RB1 radiosensitivity and } \\
\text { instability increased }\end{array}$ \\
\hline \multicolumn{2}{|l|}{ Guo et al. 2010 [73] } \\
\hline Irradiated samples: & Human fibroblasts and E2Fs \\
\hline Radiation source: & UVA, UVB, UVC \\
\hline Dose: & $290 \mathrm{~nm}$ \\
\hline $\begin{array}{l}\text { Analysis time after } \\
\text { radiation: }\end{array}$ & Up to $8 \mathrm{hrs}$ \\
\hline Sample count: & Depending \\
\hline Results: & $\begin{array}{l}\text { E2F1 stabilization in response to DNA } \\
\text { damage contributes to the induction of } \\
\text { apoptosis }\end{array}$ \\
\hline Conclusion: & $\begin{array}{l}\text { E2F1 results in the inefficient repair of } \\
\text { UV-induced DNA damage. It can inhibit } \\
\text { apoptosis and increase survival in } \\
\text { response to UV radiation }\end{array}$ \\
\hline
\end{tabular}

\section{Conclusion}

Many evidence suggests that ionizing and nonionizing radiations have different mechanisms to destroy cancer cells and play an important role in treating RB. This paper gives a brief overview of some important mechanisms of radiation for cancer therapy. Early theoretical work suggested that radiation therapy included X-ray, Gamma-ray, and other ionizing radiation, leading to cancer cells' destruction. More recent work suggests that applying Infrared, Laser, electromagnetic radiation, and other non-ionized radiation would induce the overall damages and increase radiation efficiency. The results confirm that the combination of the treatments is more effective than traditional therapeutic methods.

The mutations of $R B 1$ genes are the cause of retinoblastoma. Thus, if these genes could regenerate 
themselves by being activated again, this cancer can be cured. The future idea is to use electromagnetic radiation (ionizing or non-ionizing) to reactive the $R B 1$ genes.

Acknowledgments: I would like to appreciate everyone who played a role in accomplishing this study's goals.

Ethical Permissions: Not declared.

Conflict of Interests: Not declared.

Authors' Contributions: Nedaei K. (First author), Introduction author/Assistant (20\%); Salehi Z. (Second author), Introduction author/Original researcher/Discussion author (35\%); Alipoor B. (Third author), Methodologist/Discussion author (4\%); Jafarzadeh M. (Fourth author), Discussion author (2\%); Aljamal M. (Fifth author), Methodologist/Statistical analyst/Discussion author (35\%); Zoladl M. (Sixth author), Methodologist (4\%).

Funding/Sources: Not declared.

\section{References}

1- Carvalho INSR, Reis AH, dos Santos ACE, Vargas FR. A polymorphism in mir-34b/c as a potential biomarker for early onset of hereditary retinoblastoma. Cancer Biomark Sect A Dis Mark. 2017;18(3):313-7.

2- Cao Q, Wang Y, Song X, Yang W. Association between MDM2 rs2279744, MDM2 rs937283, and p21 rs1801270 polymorphisms and retinoblastoma susceptibility. Medicine (Baltimore). 2018;97(49):e13547.

3- AlAli A, Kletke S, Gallie B, Lam WC. Retinoblastoma for pediatric ophthalmologists. A Asia Pac J Ophthalmol (Phila). 2018;7(3):160-8.

4- Aerts I, Lumbroso-Le Rouic L, Gauthier-Villars M, Brisse H, Doz F. Retinoblastoma update. Arch Pediatr. 2016;23(1):112-6. [French]

5- de Carvalho INSR, de Freitas RM, Vargas FR. Translating microRNAs into biomarkers: What is new for pediatric cancer?. Med Oncol. 2016;33(5):49.

6- Simon GR, Baker C, Barden GA, Brown OW, Hardin A, Lessin HR, et al. 2014 recommendations for pediatric preventive health care. Pediatrics. 2014;133(3):568-70.

7- Houdayer C, Gauthier-Villars M, Laugé A, Pagès-Berhouet S, Dehainault C, Caux-Moncoutier V, et al. Comprehensive screening for constitutional RB1 mutations by DHPLC and QMPSF. Hum Mutat. 2004;23(2):193-202.

8- Li WL, Buckley J, Sanchez-Lara PA, Maglinte DT, Viduetsky L, Tatarinova TV, et al. A rapid and sensitive next-generation sequencing method to detect RB1 mutations improves care for retinoblastoma patients and their families. The J Mol Diagn. 2016;18(4):480-93.

9- Singh HP, Wang S, Stachelek K, Lee S, Reid MW, Thornton ME, et al. Developmental stage-specific proliferation and retinoblastoma genesis in RB-deficient human but not mouse cone precursors. Proc Nat Acad Sci U S A. 2018;115(40):E9391-e400.

10- Wong JR, Tucker MA, Kleinerman RA, Devesa SS. Retinoblastoma incidence patterns in the US Surveillance, Epidemiology, and End Results program. JAMA Ophthalmol. 2014;132(4):478-83.

11- Truong B, Green AL, Friedrich P, Ribeiro KB, RodriguezGalindo C. Ethnic, racial, and socioeconomic disparities in retinoblastoma. JAMA Pediatr. 2015;169(12):1096-104.

12- Andreoli MT, Chau FY, Shapiro MJ, Leiderman YI. Epidemiological trends in 1452 cases of retinoblastoma from the Surveillance, Epidemiology, and End Results (SEER) registry. Can J Ophthalmol. 2017;52(6):592-8.

13- Friedrich P, Itriago E, Rodriguez-Galindo C, Ribeiro K. Racial and ethnic disparities in the incidence of pediatric extracranial embryonal tumors. J Nat Cancer Inst. 2017;109(10).

14- Hossain MS, Begum M, Mian MM, Ferdous S, Kabir S, Sarker HK, et al. Epidemiology of childhood and adolescent cancer in Bangladesh, 2001-2014. BMC Cancer. 2016;16:104.

15- Jardel P, Caujolle JP, Gastaud L, Maschi C, Sauerwein W, Thariat J. Malignant tumours of the eye: Epidemiology, diagnostic methods and radiotherapy. Cancer Radiother. 2015;19(8):762-74. [French]

16- Musselman JRB, Spector LG, Krailo MD, Reaman GH, Linabery AM, Poynter JN, et al. The Children's Oncology Group Childhood Cancer Research Network (CCRN): Case catchment in the United States. Cancer. 2014;120(19):3007-15.

17- Temming P, Viehmann A, Biewald E, Lohmann DR. Sporadic unilateral retinoblastoma or first sign of bilateral disease?. Br J Ophthalmol. 2013;97(4):475-80.

18- de Paula Silva N, de Souza Reis R, Garcia Cunha R, Pinto Oliveira JF, de Oliveira Santos M, Pombo-de-Oliveira MS, et al. Maternal and birth characteristics and childhood embryonal solid tumors: A population-based report from brazil. PloS One. 2016;11(10):e0164398.

19- Heck JE, Contreras ZA, Park AS, Davidson TB, Cockburn M, Ritz B. Smoking in pregnancy and risk of cancer among young children: A population-based study. Int J Cancer. 2016;139(3):613-6.

20- Gao J, Zeng J, Guo B, He W, Chen J, Lu F, et al. Clinical presentation and treatment outcome of retinoblastoma in children of South Western China. Medicine (Baltimore). 2016;95(42):e5204.

21- Azary S, Ganguly A, Bunin GR, Lombardi C, Park AS, Ritz $B$, et al. Sporadic retinoblastoma and parental smoking and alcohol consumption before and after conception: A report from the children's oncology group. PloS One. 2016;11(3):e0151728.

22- Jin L, Zhang W, Pan H, Li T, Liu B, Zhao J, et al. Retrospective investigation of retinoblastoma in Chinese patients. Oncotarget. 2017;8(65):108492-7.

23- Kitajima S, Takahashi C. Intersection of retinoblastoma tumor suppressor function, stem cells, metabolism, and inflammation. Cancer Sci. 2017;108(9):1726-31.

24- Lohmann D. Retinoblastoma. In: Ahmad SI. editors. Diseases of DNA repair. Advances in experimental medicine and biology. New York: Springer; 2010.

25- Abramson DH, Shields CL, Munier FL, Chantada GL. Treatment of retinoblastoma in 2015: Agreement and disagreement. JAMA Ophthalmol. 2015;133(11):1341-7.

26- Yanagisawa T. Systemic chemotherapy as a new conservative treatment for intraocular retinoblastoma. Int J Clin Oncol. 2004;9(1):13-24.

27- Wilson MW, Haik BG, Billups CA, Rodriguez-Galindo C. Incidence of new tumor formation in patients with hereditary retinoblastoma treated with primary systemic chemotherapy: Is there a preventive effect?. Ophthalmology. 2007;114(11):2077-82.

28- Zhao J, Feng ZX, Wei M, Liu G, Solarte CE, Li B, et al. impact of systemic chemotherapy and delayed enucleation on survival of children with advanced intraocular retinoblastoma. Ophthalmol Retina. 2020;4(6):630-9.

29- Biewald E, Holdt M, Bornfeld N. New therapeutic strategies for retinoblastoma: Non-systemic 
chemotherapy. Ophthalmologe. 2014;111(4):379-82. [German]

30- Temming P, Arendt M, Viehmann A, Eisele L, Le Guin CHD, Schundeln MM, et al. Incidence of second cancers after radiotherapy and systemic chemotherapy in heritable retinoblastoma survivors: A report from the German reference center. Pediatr Blood Cancer. 2017;64(1):71-80. 31- Shields CL, Mashayekhi A, Au AK, Czyz C, Leahey A, Meadows AT, et al. The international classification of retinoblastoma predicts chemoreduction success. Ophthalmology. 2006;113(12):2276-80.

32- Shields CL, Ramasubramanian A, Thangappan A, Hartzell K, Leahey A, Meadows AT, et al. Chemoreduction for group $\mathrm{E}$ retinoblastoma: comparison of chemoreduction alone versus chemoreduction plus lowdose external radiotherapy in 76 eyes. Ophthalmology. 2009;116(3):544-551.e1.

33- Zage PE, Reitman AJ, Seshadri R, Weinstein JL, Mets MB, Zeid JL, et al. Outcomes of a two-drug chemotherapy regimen for intraocular retinoblastoma. Pediatr Blood Cancer. 2008;50(3):567-72.

34- Gombos DS, Hungerford J, Abramson DH, Kingston J, Chantada G, Dunkel IJ, et al. Secondary acute myelogenous leukemia in patients with retinoblastoma: Is chemotherapy a factor?. Ophthalmology. 2007;114(7):1378-83.

35- Tuncer S, Sencer S, Kebudi R, Tanyildiz B, Cebeci Z, Aydin K. Superselective intra-arterial chemotherapy in the primary management of advanced intra-ocular retinoblastoma: First 4-year experience from a single institution in Turkey. Acta Ophthalmol. 2016;94(7):e64451.

36- Shields CL, Bianciotto CG, Jabbour P, Ramasubramanian A, Lally SE, Griffin GC, et al. Intra-arterial chemotherapy for retinoblastoma: Report No. 1, control of retinal tumors, subretinal seeds, and vitreous seeds. Arch Ophthalmol. 2011;129(11):1399-406.

37- Shields CL, Bianciotto CG, Jabbour P, Griffin GC, Ramasubramanian A, Rosenwasser R, et al. Intra-arterial chemotherapy for retinoblastoma: Report No. 2, treatment complications. Arch Ophthalmol. 2011;129(11):1407-15.

38- Abramson DH, Fabius AWM, Francis JH, Marr BP, Dunkel IJ, Brodie SE, et al. Ophthalmic artery chemosurgery for eyes with advanced retinoblastoma. Ophthalmic Genet. 2017;38(1):16-21.

39- Munier FL, Mosimann P, Puccinelli F, Gaillard MC, Stathopoulos C, Houghton S, et al. First-line intra-arterial versus intravenous chemotherapy in unilateral sporadic group D retinoblastoma: Evidence of better visual outcomes, ocular survival and shorter time to success with intra-arterial delivery from retrospective review of 20 years of treatment. Br J Ophthalmol. 2017;101(8):1086-93. 40- De Francesco S, Galluzzi P, Bracco S, Menicacci F, Motolese E, Hadjistilianou T. Alternated intra-arterial and intravitreal chemotherapy for advanced intraocular retinoblastoma: Preliminary successful results without systemic chemotherapy. Int Ophthalmol. 2015;35(6):88795.

41- Ghassemi F, Shields CL. Intravitreal melphalan for refractory or recurrent vitreous seeding from retinoblastoma. Arch Ophthalmol. 2012;130(10):1268-71. 42- Munier FL, Gaillard MC, Balmer A, Soliman S, Podilsky G, Moulin AP, et al. Intravitreal chemotherapy for vitreous disease in retinoblastoma revisited: From prohibition to conditional indications. Br J Ophthalmol. 2012;96(8):107883.
43- Shields CL, Manjandavida FP, Arepalli S, Kaliki S, Lally SE, Shields JA. Intravitreal melphalan for persistent or recurrent retinoblastoma vitreous seeds: Preliminary results. JAMA Ophthalmology. 2014;132(3):319-25.

44- Tuncer S, Balci O, Tanyildiz B, Kebudi R, Shields CL. Intravitreal lower-Dose $(20 \mu \mathrm{g})$ melphalan for persistent or recurrent retinoblastoma vitreous seeds. Ophthalmic Surg Lasers Imaging Retina. 2015;46(9):942-8.

45- Ji X, Hua P, Li J, Li J, Zhao J, Zhao P. Intravitreal melphalan for vitreous seeds: Initial experience in China. J Ophthalmol. 2016;2016:4387286.

46- Francis JH, Brodie SE, Marr B, Zabor EC, MondesireCrump I, Abramson DH. Efficacy and toxicity of intravitreous chemotherapy for retinoblastoma: Four-year experience. Ophthalmology. 2017;124(4):488-95.

47- Jimenez H, Blackman C, Lesser G, Debinski W, Chan M, Sharma S, et al. Use of non-ionizing electromagnetic fields for the treatment of cancer. Front Biosci (Landmark Ed). 2018;23:284-97.

48- Daud AI, DeConti RC, Andrews S, Urbas P, Riker AI, Sondak VK, et al. Phase I trial of interleukin-12 plasmid electroporation in patients with metastatic melanoma. J Clin Oncol. 2008;26(36):5896-903.

49- Beebe SJ, Ford WE, Ren W, Chen X, Schoenbach KH. Non-ionizing radiation with nanosecond pulsed electric fields as a cancer treatment: In vitro studies. Annu Int Conf IEEE Eng Med Biol Soc. 2009;2009:6509-12.

50- Davalos RV, Mir IL, Rubinsky B. Tissue ablation with irreversible electroporation. Ann Biomed Engin. 2005;33(2):223-31.

51- Shirasu N, Nam So, Kuroki M. Tumor-targeted photodynamic therapy. Anticancer Res. 2013;33(7):282331.

52- Wei Y, Lu C, Chen Q, Xing D. DNA duplex-based photodynamic molecular beacon for targeted killing of retinoblastoma cell. Investig Ophthalmol Vis Sci. 2016;57(14):6011-9.

53- Aerts I, Leuraud P, Blais J, Pouliquen AL, Maillard P, Houdayer $\mathrm{C}$, et al. In vivo efficacy of photodynamic therapy in three new xenograft models of human retinoblastoma. Photodiagn Photodyn Ther. 2010;7(4):275-83.

54- Walther J, Schastak S, Dukic-Stefanovic S, Wiedemann $P$, Neuhaus J, Claudepierre T. Efficient photodynamic therapy on human retinoblastoma cell lines. PloS One. 2014;9(1):e87453.

55- Tsai SR, Hamblin MR. Biological effects and medical applications of infrared radiation. J Photochem Photobiol B Biol. 2017;170:197-207.

56- Anders JJ, Lanzafame RJ, Arany PR. Low-level light/laser therapy versus photobiomodulation therapy. Photomed Laser Surg. 2015;33(4):183-4.

57- Passarella S, Karu T. Absorption of monochromatic and narrow band radiation in the visible and near IR by both mitochondrial and non-mitochondrial photoacceptors results in photobiomodulation. J Photochem Photobiol B Biol. 2014;140:344-58.

58- Karu TI. Mitochondrial signaling in mammalian cells activated by red and near-IR radiation. Photochem Photobiol. 2008;84(5):1091-9.

59- de Freitas LF, Hamblin MR. Proposed Mechanisms of Photobiomodulation or Low-Level Light Therapy. IEEE J Sel Top Quantum Electron. 2016;22(3): 7000417.

60- Santana-Blank LA, Rodríguez-Santana E, SantanaRodríguez KE. Photo-infrared pulsed bio-modulation (PIPBM): A novel mechanism for the enhancement of 
A Review of Outstanding Retinoblastoma Researches on RB1 Genes ...

physiologically reparative responses. Photomed Laser Surg. 2005;23(4):416-24.

61- König A, Zöller N, Kippenberger S, Bernd A, Kaufmann $\mathrm{R}$, Layer PG, et al. Non-thermal near-infrared exposure photobiomodulates cellular responses to ionizing radiation in human full thickness skin models. J Photochem Photobiol B Biol. 2018;178:115-23.

62- Künzli BM, Liebl F, Nuhn P, Schuster T, Friess H, Hartel M. Impact of preoperative local water-filtered infrared A irradiation on postoperative wound healing: A randomized patient- and observer-blinded controlled clinical trial. Ann Surg. 2013;258(6):887-94.

63- Ram R, Uziel O, Eldan O, Fenig E, Beery E, Lichtenberg $\mathrm{S}$, et al. Ionizing radiation up-regulates telomerase activity in cancer cell lines by post-translational mechanism via ras/phosphatidylinositol 3-kinase/Akt pathway. Clin Cancer Res. 2009;15(3):914-23.

64- Sun B, Chen M, Hawks CL, Pereira-Smith OM, Hornsby PJ. The minimal set of genetic alterations required for conversion of primary human fibroblasts to cancer cells in the subrenal capsule assay. Neoplasia. 2005;7(6):585-93.

65- Akiyama M, Ozaki K, Kawano T, Yamada O, Kawauchi K, Ida $\mathrm{H}$, et al. Telomerase activation as a repair response to radiation-induced DNA damage in Y79 retinoblastoma cells. Cancer Lett. 2013;340(1):82-7.

66- Lim Z, Quah BL. Unilateral retino blastoma in an eye with Peters anomaly. J Am Assoc Pediatr Ophthalmol
Strabismu. 2010;14(2):184-6.

67- Kanber D, Berulava T, Ammerpohl O, Mitter D, Richter $\mathrm{J}$, Siebert R, et al. The human retinoblastoma gene is imprinted. PloS Genet. 2009;5(12):e1000790.

68- Wilson PF, Nagasawa H, Fitzek MM, Little JB, Bedford JS. G2-phase chromosomal radiosensitivity of primary fibroblasts from hereditary retinoblastoma family members and some apparently normal controls. Radiat Res. 2010;173(1):62-70.

69- Yang Y, Tian S, Brown B, Chen P, Hu H, Xia L, et al. The $\mathrm{Rb} 1$ gene inhibits the viability of retinoblastoma cells by regulating homologous recombination. Int J Mol Med. 2013;32(1):137-43.

70- Knudsen ES, Sexton CR, Mayhew CN. Role of the retinoblastoma tumor suppressor in the maintenance of genome integrity. Curr Mol Med. 2006;6(7):749-57.

71- Attwooll C, Lazzerini Denchi E, Helin K. The E2F family: Specific functions and overlapping interests. EMBO J. 2004;23(24):4709-16.

72- Chen J, Zhu F, Weaks RL, Biswas AK, Guo R, Li Y, et al. E2F1 promotes the recruitment of DNA repair factors to sites of DNA double-strand breaks. Cell Cycle. 2011;10(8):1287-94.

73- Guo R, Chen J, Zhu F, Biswas AK, Berton TR, Mitchell DL, et al. E2F1 localizes to sites of UV-induced DNA damage to enhance nucleotide excision repair. J Biol Chem. 2010;285(25):19308-15. 